\title{
Identification of Aves, Herpetofauna and Arthropods in Miangas Island (Indonesia), the borderline of Wallacea ecoregion
}

\author{
ADY SURYAWAN", ISDOMO YULIANTORO, ANITA MAYASARI, MARGARETTA CHRISTITA \\ Environment and Forestry Research and Development Instute of Manado. Jl. Raya Adipura, Kima Atas, Mapanget, Manado 95259, North Sulawesi, \\ Indonesia. Tel./fax.: +62-431-3666683, `email: suryawanbioconserv@gmail.com \\ Manuscript received: 31 August 2016. Revision accepted: 2 October 2017.
}

\begin{abstract}
Suryawan A, Yuliantoro I, Mayasari A, Christita M. 2016. Identification of Aves, Herpetofauna and Arthropods in Miangas Island (Indonesia), the borderline of Wallacea ecoregion. Biodiversitas 18: 1528-1537. Miangas Island is located on the northeast of Wallacea and bordered by the Philippines and it belongs to Talaud archipelago. This study aims to identify the species of terrestrial wildlife in Miangas Island. Observations used the direct encounter method starting at 7:00 to 17:00 pm and they were conducted through four times visits in October and December 2015, April and May 2016. Some species were found, such as 15 species of birds, 3 species of lizards, 1 snake and 1 species of Arthropods. Hirundapus caudacutus and Butastur indicus are migrant bird species. Lamprolepis smaragdina is green and classified as tree climber type. It is included to hybrid lizard type of the Pacific and the Philippines. Based on IUCN database, Eos histrio is classified as endangered group (E), Ducula pickeringii as vulnerable (V) Todirhamphus enigma enigma is classified as near threatened group (NT), Birgus latro is classified as Data deficient (DD), while Butastur indicus, Lanius Schach, Nectarinia jugular plateni, Todirhamphus chloris, Hirundo tahitica, Hirundapus caudacutus, Egretta sacra, Ardea alba, Anthus cervinus, Motacilla cinerea, Cuculus saturatus, Passer Montanus, Ducula pickeringii, Eutropis multicarinata multicarinata, Lamprolepis smaragdina, Emoia caeruleocauda and Laticauda laticauda are classified as low risk (LC).
\end{abstract}

Keywords: Miangas, species diversity, Wallacea, wildlife

\section{INTRODUCTION}

Based on the explanation of Lubis (2014), Miangas has a geostrategic role because of its position as the outer island of Indonesia and based on Sarbidi (2010) it is categorized as a small island with an area of $3.15 \mathrm{~km}^{2}$. Administratively, the Miangas Island is included to the Talaud Archipelago Regency, North Sulawesi Province. Miangas Island is bounded by the Pacific Ocean on the east and south, Sulawesi Sea on the south and The Philippines on the west and north (BPS 2014).

45 million years ago, tectonic and geological activity caused Sulawesi Island and its surrounding islands, especially Miangas which was derived from the same cluster with a maritime Philippines (Stelbrink 2014 and Stelbrink et al. 2012). Miangas was considered as an isolated island because of its distance to the Mindanao island (Philippines) namely 48 nautical miles and to Nanusa Island (Indonesia) namely 145 nautical miles (BPS 2014).

Miangas Island is included to the Northeast of Wallacea ecoregion based on the original line of Wallacea (Coates and Bishop 2000) and the map of Cept.net (2016). This insulating effect will reduce biodiversity (Purnomo et al. 2015). This statement is in line with Woodruff (2010) which explains that the principle of island biogeography has a positive correlation between the wide of the island and the number of biodiversities. Longer distance of an island from the main island will reduce species diversity but will increase endemic. Saryanti (2013) explains that
$80 \%$ of the forest area of Wallacea is currently in degraded condition and at least 535 species are endangered. This condition becomes a serious note for conservationists. Miangas Island as a small habitat will affect genetic flow, genetic drift, and fitness and become a factor against extinction rate especially for endangered species (Mbora and McPeek 2010).

The Talaud Island is the northernmost part of Wallacea Ecoregion where two endemic bird species, namely Talaud Bush-hen (Amaurornis magnirostris), Taluad Rail (Gymnocrex taluadensis), have small population in primary forest. Talaud island also as the habitat of EndangeredVulnerable species i.e. Eos histrio, Tanygnathus lucionensis, Halcyon enigma, Ducula concinna and Ducula pickeringii (Riley 2003). While Burung.org (2010) explains that there are 10 species of endemic birds in the SangiheTalaud islands, namely, Ducula pickeringii, Eos histrio, Loriculus catamene, Ceyx fallax, Cittura cyanotis, Todiramphus enigma, Coracina bicolor, Eutrichomyias rowleyi, Aethopyga duyvenbodei, and Ducula concinna.

Based on Koch et al. (2009) there are two types of herpetofauna in Miangas Island, i.e. Lamprolepis smaragdina and Eutropis multifasciata. L. smaragdina is a type of the Philippines and Pacific taxa hybrid. Koch et al. (2013) have described a new cryptic member of the mangrove monitor (Varanus indicus) from Talaud Island, based on morphological and molecular evidence. However, from such references that have been obtained, there is no specific wildlife biodiversity of Miangas Island. Based on preliminary research, it is known that Miangas Island is 
dominated by three taxa, they are herpetofauna, aves, and arthropods, while mammals are less. This study aims to provide information on wildlife biodiversity on a remote island in the transitional region of two Asian bioecoregions and Wallacea which has not been previously reported.

\section{MATERIALS AND METHODS}

\section{Study area}

The research was conducted in Miangas Island of North Sulawesi, Indonesia in 2 to 4 November 2015, in 14 to 16 December 2015, in 20 to 22 April 2016 and 25 to 27 May 2016. Observations were conducted at 07-10 and 16.3017.00. The location was along the coastal of Miangas, mangrove, coconut plantation area and prairie, with a width of $3.5 \mathrm{~km}$ at an elevation of 0-98 meters above sea level.

\section{Materials}

The research material was Miangas ecosystem. The equipments were DSLR camera, GPS, and book: Field Guide introduction of bird species (Coates and Bishop 2000).

\section{Procedures}

The study was conducted through direct observation referring to operational standards by Fachrul (2008) using transect point on bird, Bismark (2011) using visual encounter survey (VES) on herpetofauna and arthropods. These methods were done by walking along thetransects determined. The observations were done during the day. Observations resulted photographic documentations and then the species identification was done using the field guides (Coates and Bishop 2008; Koch et al. 2009 and Motoh and Kuronuma 1980) and information from IUCN Redlist.org, Birdlife.org and some scientific journals of each species about conservation status, distribution and characteristic.

\section{Data analysis}

Data were analyzed and presented descriptively including the habitat, distribution, the wild population, and conservation status by the International Union for Conservation Nature and Natural Resources (IUCN 2016), Birdlife International (Birdlife.org 2016).

\section{RESULTS AND DISCUSSION}

\section{Results}

The study was conducted at the hand of the east, southwest and center of the island. This is done because in the north and southwest, the areas have been opened for the use of airport construction, so the animals encounter relatively low. The study found 15 species of birds, 4 species of reptiles and one species of crustaceans.
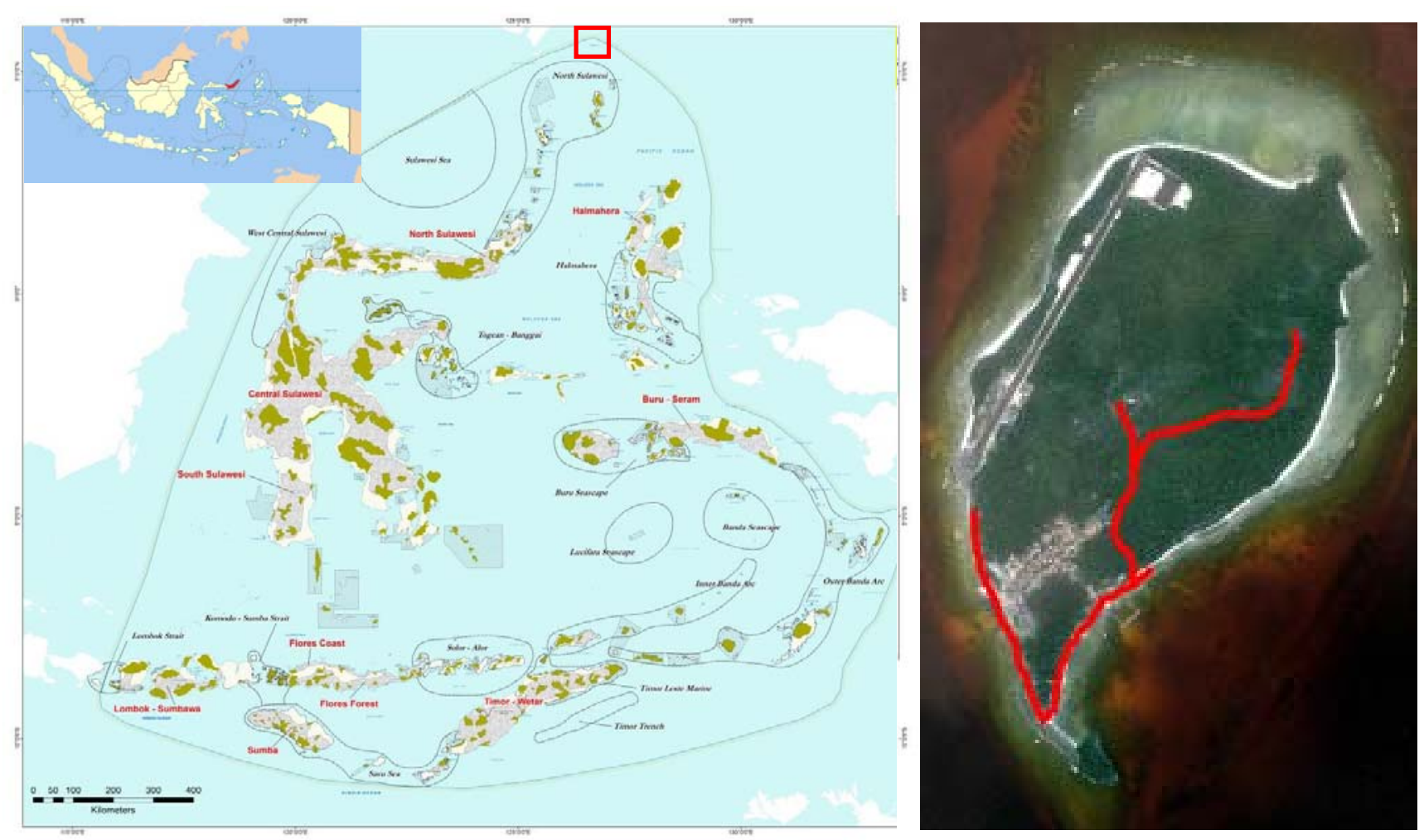

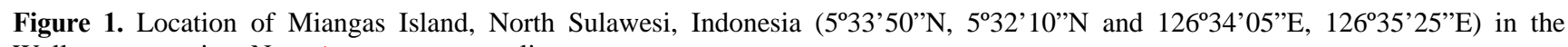
Wallacea ecoregion. Note: $\sim$ transect line 


\section{Identification of birds}

Grey Faced Buzzard, Butastur indicus (Family: Accipitridae)

Grey faced buzzard (Figure 2.A) was found in a coconut and tall trees, i.e., banyan, but it often flew to stalk the prey. The Solo Hill is an ideal location for raptor observation because it is an ideal place to observe the whole landscape of Miangas. It had distribution area of 1.830.00 $\mathrm{km}^{2}$, including Japan, South Korea, and North Korea and migrated to Southeast Asia over Thailand, Malaysia, Sumatra, Java, Kalimantan (Borneo), Sulawesi and North Moluccas (BirdLife 2016). According to Coates and Bishop (2000), it can be found at Karakelong Islands, Salibabu Island, Sangihe Islands, Siau Island, Sula Island, Morotai Island, Halmahera Island and Ternate Island in September to March. BirdLife (2016) released the information that its populationwas more than 100,000 birds in 2001. It is considered as low risk (LC) species based on IUCN Redlist.

\section{Long tail shrike, Lanius schach (Family: Laniidae)}

Long tail shrike (Figure 2.B) was found in an open area bordered by mangrove ecosystems at 4 meters above sea level. This area provides various types of insects as food. The bird has $11.200 .00 \mathrm{~km}^{2}$ of distribution area covering Afghanistan, Pakistan, Southeast Asia, to Papua New Guinea (BirdLife 2016). Whilst, according to Caotes and Bishop (2000), the distribution has a limited area to Nusa Tenggara covering the islands of Lombok, Sumbawa, Alor, Timor, Wetar and Kisar. According to BirdLife (2016), the birds' populations reached $10000-100000$ pairs, then, by the IUCN, it is categorized as low risk (LC) to extinction.

\section{Olive Backed Sunbird, Nectarinia jugularis plateni (Family: Nectariniidae)}

Olive-backed sunbird (Figure 2.C) spread evenly from coconut plantations on the coast to the hills at an altitude of 75 meters above sea level. It reaches 5,200,000 $\mathrm{km}^{2}$ spreading area covering the whole of Southeast Asia, Papua New Guinea, Northern Australia (BirdLife 2016). Coates and Bishop (2000) split it into two groups based on the color of the abdomen. One sub-type is N.j. platen, a yellow-bellied group. Its habitat includes coastal areas and small islands such as Talaud, Sangihe, Siau, Bangka Island, Manado Tua, Togian Islands and Selayar. According to BirdLife (2016), its population has not been studied, but this species is common and has a stable population trend, so it is categorized as low risk of extinction (LC).

\section{Collared Kingfisher, Todirhamphus chloris (Family: Alcedinidae)}

Collared kingfisher (Figure 2.D) was found in coastal areas ranging from beaches, mangrove forests until the coconut grove which was far from the sea. BirdLife (2016) mentions that it is a wide distribution species, reaching $3,940,000 \mathrm{~km}^{2}$ covering an area of northern Australia, Southeast Asia, the Pacific island countries, and parts of India, Saudi Arabia, Ethiopia and Yemen. There is a conclusion that the population is declining, but it has not been calculated yet exactly, and it is categorized as low risk (LC) by IUCN.

Talaud kingfisher, Todirhamphus enigma enigma (Family: Alcedinidae)

Talaud kingfisher (Figure 2.E) was found in the coastal areas covering beaches, mangrove forests to the coconut plantations near the beaches. BirdLife (2016) mentioned that it has a distribution of $1,000 \mathrm{~km}^{2}$ as an endemic species on the island of Karakelong, Salebabu and Kabaruang. This endemicity has been declared by Coates and Bishop (2000) that Talaud kingfisher is endemic to Islands of Talaud, which includes Karakelong Talaud Island, Salebabu and some areas of North Sulawesi subregions. Riley (2003) has estimated the population Talaud Kingfisher in Karakelang was 5290-8690 individuals with low density, and it should be considered as threatened (VU). Based on IUCN (2016), the status of this species has approached Near Threatened (NT).

Pacific swallow, Hirundo tahitica (Family: Hirundinidae)

Pacific swallow (Figure 2.F) was easily found flying along the coast of Miangas. BirdLife (2016) said that it has a distribution of 3.36 million $\mathrm{km}^{2}$ covering Indonesia, the Philippines, Malaysia, Singapore, southern Thailand, and the Pacific island countries. It was considered as increasing population trend, and categorized as low risk conservation status according to IUCN (2016).

\section{White-throated needletail, Hirundapus caudacutus (Family: Apodidae)}

White-throated needletail (Figure 2.G) was found flying across the upperside of the Solo hill or a prairie. According to Coates and Bishop (2000), white-throated needle tail was a migratory bird which stopped in this area on September until early April. It can be found at Wallacea ranging from Sangihe archipelago to the islands of Lombok and East Banda. BirdLife (2016) has concluded that its distribution area reaches 3.72 million $\mathrm{km}^{2}$, and has presented a map of non-native breeding area covering eastern parts of Australia such as Sydney, Victoria, New South Wales, Queensland, Papua New Guinea, and the native breeding area in East Asia including Japan, North Korea, South Korea, Mongolia and China. Based IUCN (2016), these species are categorized into low risk of extinction (LC).

\section{Pacific reef-egret, Egretta sacra (Family: Ardeidae)}

Pacific reef-egret (Figure 2.H) was found in the afternoon and flying over the beach of east Miangas. Coates and Bishop (2000) explained that the Pacific reefegret is also a natural resident of beach with coral reefs. It is widespread in Wallacea ranging from the island of Talaud-Sangihe-Siau, Talise, North Halmahera, Seram, Ambon, Nusa Tenggara to islands of Tanimbar. BirdLife (2016) explained that the Pacific reef egrets have an extensive distribution i.e. 4.1 million $\mathrm{km}^{2}$ covering the coast of Asia, Australia, Papua New Guinea and the Pacific island countries. It had a stable population trend and based on the IUCN, it is classified as low risk of extinction 
White Egret, Ardea alba (Family: Ardeidae)

The white egret (Figure 2.I) was easily found around the mangrove forest on Miangas Island. According to Coates and Bishop (2000), this species was found in a variety of wetland ecosystems such as mangrove, swamp, lakes at an altitude of Sub-tropical countries with widespread reach 57.2 million $\mathrm{km}^{2}$. BirdLife (2016) stated that the data of growth population and its trend was unknown. Currently, the white egret is classified as low risk of extinction (LC) by IUCN (2016).

Red-throated pipit, Anthus cervinus (Family: Motacillidae)

Red throated pipit (Figur 2.J) was found roosting in branches around the Solo Hill. According to Coates and Bishop (2000), it is a kind of nomad bird in Wallacea and often flew over the coastal areas to the highlands and other specific area near the water. Based on BirdLife (2016), this species has a distribution of $3,790,000 \mathrm{~km}^{2}$. In Asia, the population spread in north of the equator area, covering Kalimantan, Sangihe, Talaud, the Philippines, Singapore, Malaysia, Thailand, Myanmar, into Northern China. This species can also be found in African continent including Kenya, Somalia, Ethiopia, Nigeria, the coast of Egypt, Libya, Tunisia to Southern Europe such as Turkey and Greece. The population was relatively stable and categorized low-risk of extinction.

\section{Grey Wagtail, Motacilla cinerea (Family: Motacillidae)}

The Grey Wagtail (Figure 2.K) was usually found around the mangroves. The observations showed that the Grey Wagtail moved by running. According to Coates and Bishop (2000), it is a common visitor in August to the beginning of May. It usually flew over the open areas, riverbanks at altitudes of 0 to 2,000 meters above sea level. It was found in various locations in the Wallacea region. The distribution area reached 16.6 million $\mathrm{km}^{2}$ covering Southeast Asia, Eastern Asia, Northern Africa and Southern Europe. BirdLife (2016) mentions that it has a stable population trend and is classified as low risk of extinction (LC)

\section{Himalayan Cuckoo Cuculus saturatus (Family: Cuculidae)}

Himalayan Cuckoo (Figur 2.L) was usually found around the coast and perching on power lines. According to Coates and Bishop (2000) this bird is a migratory bird in September to early of June. Himalayan Cuckoo visits the area of cultivation, forest edges, savanna. It is migratory birds from Asia that has sub type of C. s. saturatus spreading in Talaud Islands, Sangihe, Ternate, Morotai to Nusa Tenggara archipelagos. The other sub-type is C.s. lepidus. IUCN (2016) concluded that it has a stable population growth trend, although there is no definitive data, it is classified as a low risk of extinction species.

\section{Grey Imperial Pigeon, Ducula pickeringii (Family: Columbidae)}

Grey Imperial Pigeon (Figur 2.M) was rarely found on a small island. Coates and Bishop (2000) explained that it inhabited the primary and secondary forest, in the coastal areas, in Karakelang, Salebabu and Kabaruang Island.
BirdLife (2016) released data on bird populations globally and it mentioned that the number of Eurasian tree sparrows ranged from 159 million to 576 million individuals. Based on IUCN (2016), this species is categorized as low risk of extinction (LC).

\section{Eurasian Tree Sparrow, Passer montanus (Family: Passeridae)}

Eurasian Tree Sparrow (Figure 2.N) was found around the housing of residents at the villages. Based on Fitzsimon et al. (2011) this bird belonged to the type of introduction and was first reported to be located in the northern part of central Sulawesi then spread to North Sulawesi. Coates and Bishop (2000) explain that it has spread over the whole of Wallacea. Based on the memoirs, it has spread to the Islands of Siau, Sangihe, Talaud, Sulawesi, Sula, Halmahera, Buru, and Lombok. The distribution reached 38.4 million $\mathrm{km}^{2}$ covering the whole of Europe and most of Asia. BirdLife (2016) released data on bird populations globally which stated that the populations of Eurasian tree sparrow ranged from 159 million to 576 million individuals and based on IUCN (2016) this species was categorized as low risk of extinction (LC).

\section{Red and Blue Lory Eos histrio talautensis (Family: Psittacidae)}

Coates and Bishop (2000) mentioned that Red and Blue Lory (Figure 2.O) are inhabitats of the primary forest and hill, but they also visit coconut plantations in the coastal areas. Distribution: Red and Blue Lory is endemic to Talaud Islands, such as in Miangas (E.h challengeri), Karekelong Island, Salebabu and Kaburuang (E.h talautensis) and Sangihe Island, Siau, Ruang (E.h histrio). Arini (2014) estimated that its population was only 2229.33 individuals which were only found on the Karakelang Island. However, this study encountered an individual of this type around the houses. Based on confirmation, this type was imported from the island Karakelang and taken by boat, so it was believed that this type of Eos was actually histrio talautensis not E.h. chalengeri. IUCN (2016) categorized this species as endangered, and Appendix 1 of CITES.

\section{Identification of Herpetofaunas}

\section{Eutrophic lizard, Eutropis multicarinata (Family:}

Scincidae)

Eutropis multicarinata (Figur 3.A) is one of twentyeighth species belonging to family of Scincidae (Datta-roy et al. 2015), this species can be differentiated from the phonetically similar species, i.e. E. rudis and E. multifasciata, by the absence of postnasal scales and five or seven strong keels on nuchals, dorsals and laterals (Koch et al. 2009). It was common and easy to find this species in the garden. It was usually found among piles of litters. Its life has adapted to a semi-arboreal life style, because it would climb tree trunks when it was being chased. Dattaroy et al. (2015) said that this Scindae Genus is the most widespread lizard groups in tropical Asia. Koch et al. (2009) suggested that this species has distribution until the east southernmost in the Salibabu Island. The island is 
located about 145 nautical miles from Miangas. Beukema (2011) mentioned that the lizard is not classified in the red list of IUCN Redlist data base.
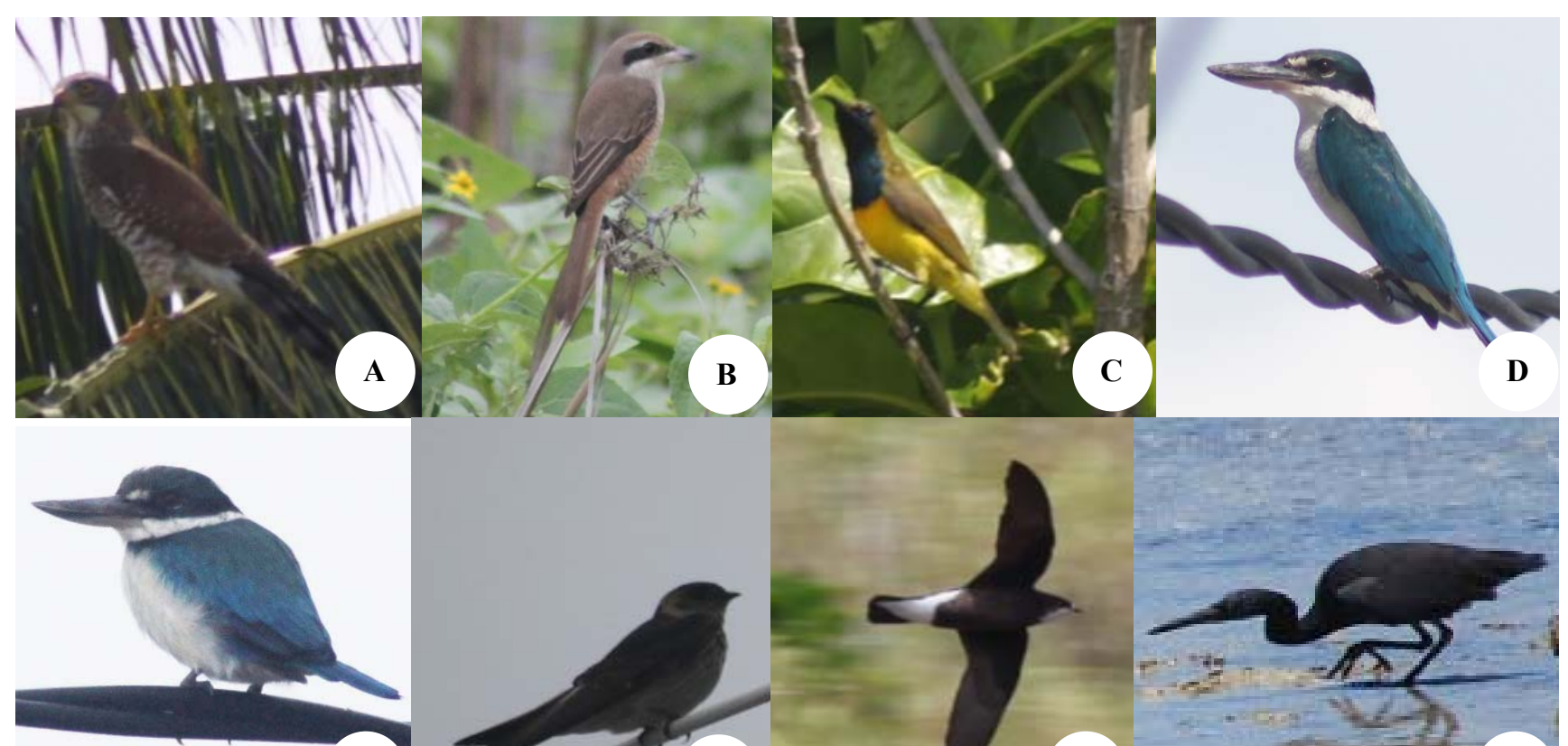

$\mathbf{E}$
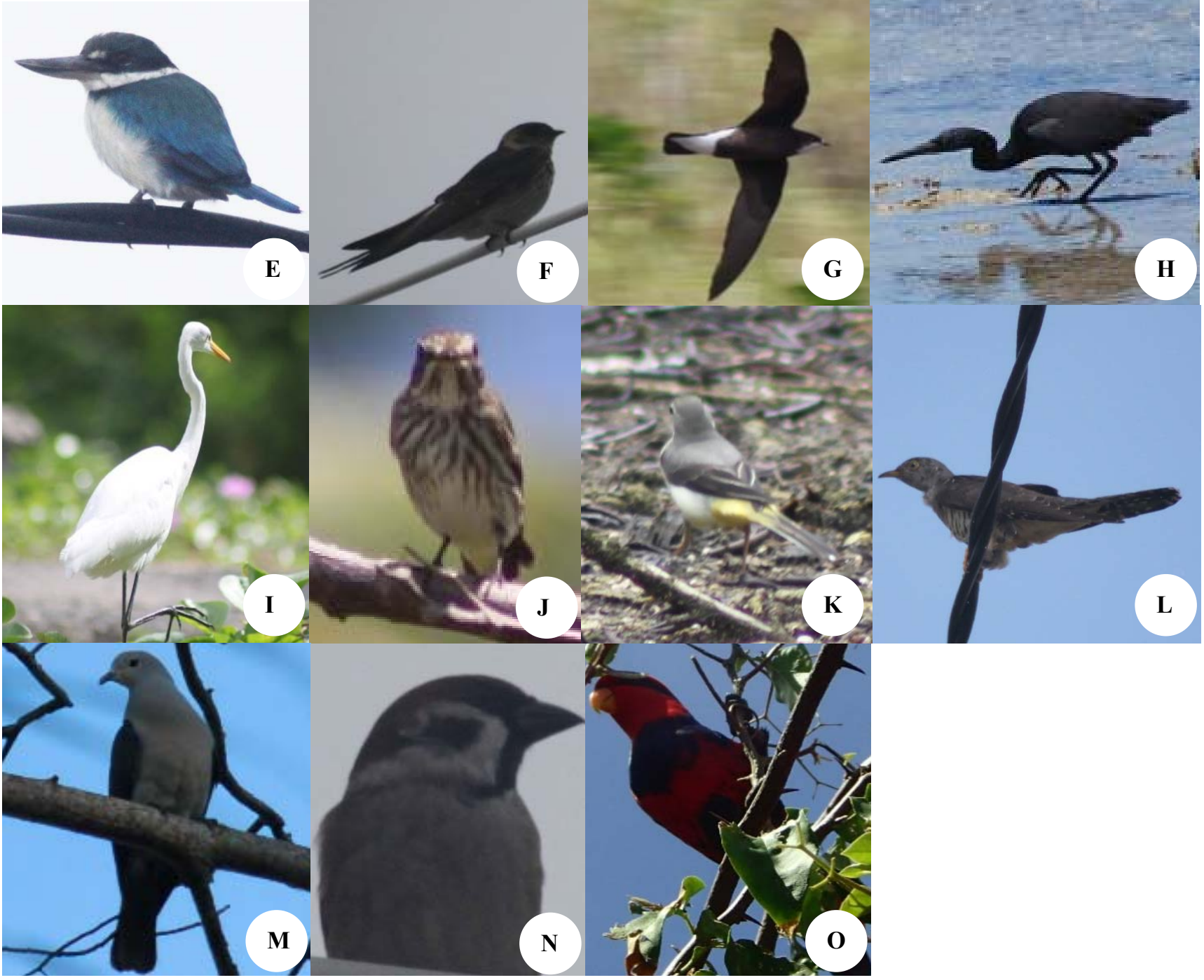

Figure 2. Various species of birds in Miangas Island, Indonesia. A. Butastur indicus, B. Lanius schach, C. Nectarinia jugularis, D. Todirhamphus chloris,E. Todirhamphus enigma enigma, F. Hirundo tahitica, G. Hirundapus caudacutus, H. Egretta sacra, I. Ardea alba, J. Anthus cervinus, K. Motacilla cinerea, L. Cuculus saturatus, M. Ducula pickeringii, N. Passer montanus, O. Eos histrio talautensis 
Pacific bluetail skink, Emoia caeruleocauda (Family: Scincidae)

The Pacific bluetail skink (Figure 3.B) is common and easy to find in the garden, usually among piles of litter. Based on IUCN (2016), It is often found in open forest are, community gardens and orchards with a maximum altitude of 400 meters above sea level. Its spreading includes the Pacific islands such as Solomon, Marshal, Bismark, Fiji, and Indonesian islands such as Papua, Maluku, Kalimantan, and Miangas Island. This species is also found in Malaysia and the Philippines. The populations are relatively stable and are not the threatened habitat. According to IUCN (2016), this species is categorized as low risk of extinction.

The Emerald Tree Skink, Lamprolepis smaragdina (Family: Scincidae)

The emerald tree skink (Figure 3.C) is easily found in gardens, it usually climbs a coconut tree and other trees. Koch et. al. (2009) mentioned that it is a hybrid of Pacific and Philippine taxa. It is an arboreal lizard in lowlands with light wood or thick forest(Kaiser et al. 2011). Based on Phylogenetic analysis, this species is divided into more than 40 sub-species and spreads in Wallacea and the Pacific Islands (Linkem et al. 2013). According to Hamidy and Mulyadi (2007), this species is not protected and belongs to non-CITES Appendix. It was categorized as low-risk to extinction (LC) in 2011 by category of IUCN (2016).

\section{Columbrine Sea Krait, Laticauda laticauda (Family: Elapidae)}

The natural habitat of Columbrine Sea Krait (Figure 3.D) is in the sea but it can be found on the embankment of abrasion in the island of Miangas. According to IUCN (2016) these snakes live in an area which ismaximal of 50 meters below sea level, and it can be found in the eastern Indian Ocean, the Pacific Ocean to the north, central and western area of it. Its populations are stable and unfragmented habitat, then they are categorized as low risk (LC).

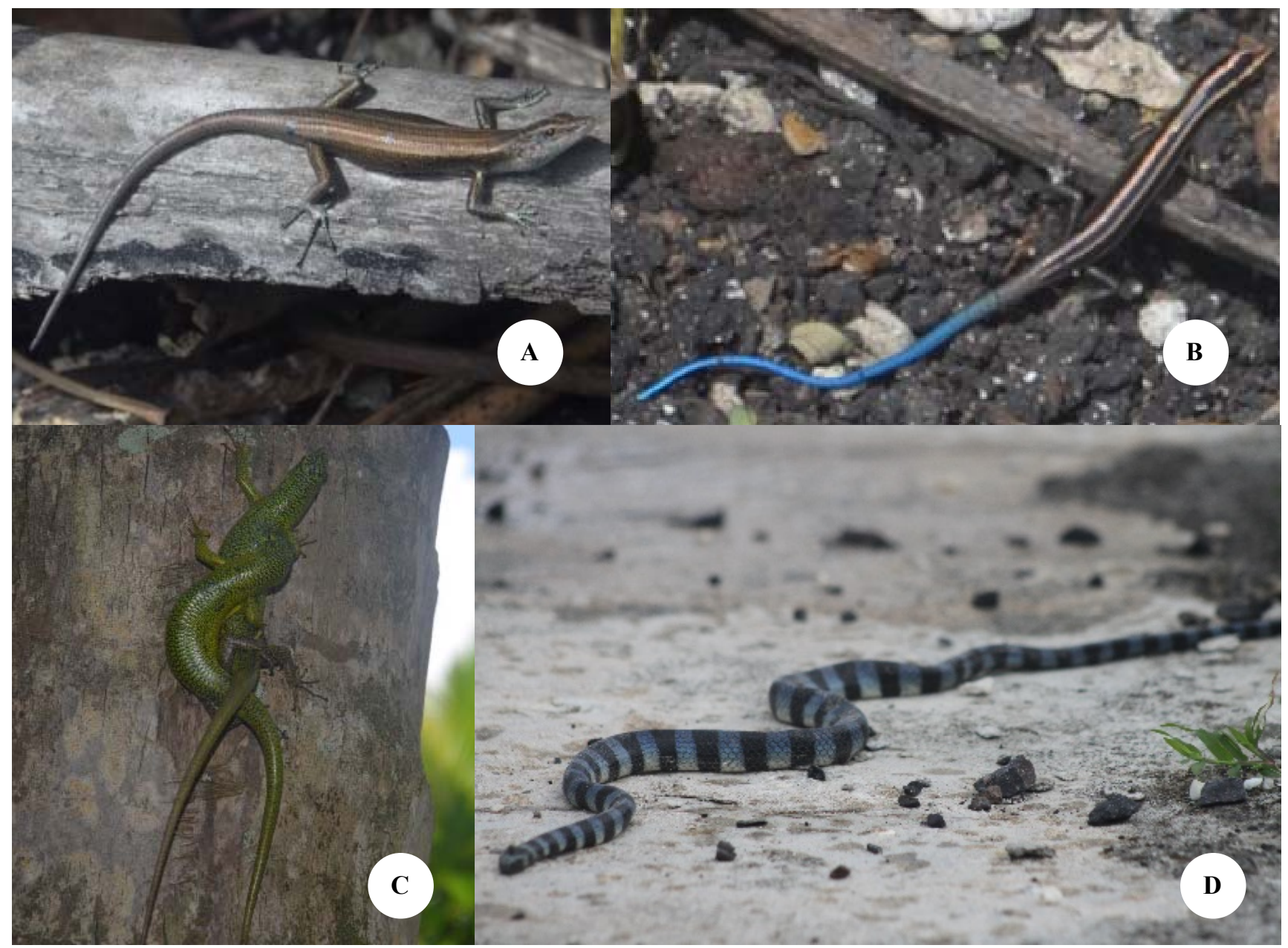

Figure 3. Various types of Herpetofaunas in Miangas Island, Indonesia. A. Eutropis multicarinata, B. Emoia caeruleocauda, C. Lamprolepis smaragdina, D. Laticauda laticauda 


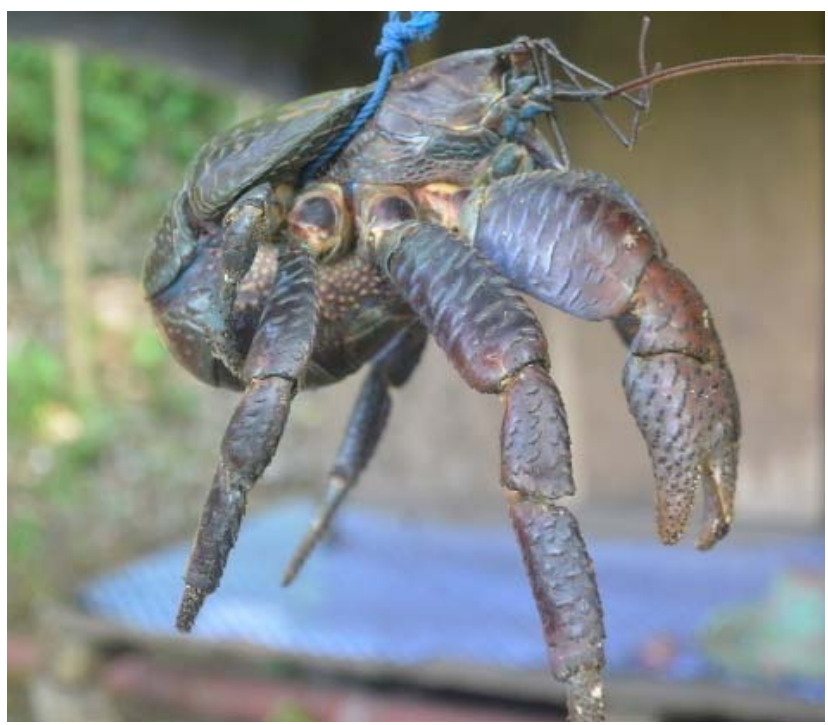

Figur 4. One of Arthropods in Miangas Island, Indonesia

\section{Identification of Arthropods}

Coconut Crab, Birgus latro (Family Coenobitidae)

Coconut crab (Figure 4) will be easy to find at night among the fallen coconuts. According to IUCN (2016), this species is solitary and lives alone by making a hole under the ground or rock to avoid predators and water loss. Sulistiono et al. (2009a) described that this species spreads out in the Western Pacific Ocean to the eastern Indian Ocean, usually is found at the rocky island but not at atoll because of the inadequate availability of food. Drew and Hansson (2014) explained that it is widely distributed on remote tropical islands in the Pacific and Indian Oceans. Christmas Island (Indian Ocean) is currently thought to be one of the places with the largest population reaching 962 individual. According to Anagnostou and Schubart (2014), in 1981, Birgus lastro has been grouped on vulnerable species. It has been reassessed as "Data Deficient (DD)" since 1996.

\section{Discussion}

Biodiversity

This research has found 15 species of birds, 3 species of lizards, 1 species of snake and 1 species of arthropods. Based on IUCN (2016), there are 1 species included in the endangered group (E), 1 species as Vulnerable (V), 1 species as in the near threatened group (NT), 1 species as data deficient (DD), 17 species classified as low risk (LC).

The diversity of bird species in Miangas is lower than that in 90 hectares of Pulau Rambut (Kepulauan Seribu National Park) which is found 24 species of birds (Alamsyah and Marhento 2016), that on Ternate Island which is found 21 species of birds (Ahmad et al. 2017), but higher than that in Pasoso Wildlife Reserve (64 hectares) which is found 14 species (Karar et al. 2016).

Butastur indicus (Grey Faced Buzzard) and $H$. caudacutus (white-throated needletail) are migrant bird species. One species identified as an endemic species is $E$. histrio. E. histrio (Red and Blue Lory) which found in Miangas Island is an introduction species from Karakelang Island. Arini et al. (2016) explained that E. histrio consists of three sub-species of E. histrio challengeri, Eos histrio histrio and Eos histrio talautensis. E.h. talautensis is currently only found in 6 big trees in SM Karakelang, Talaud. Indrawan (2005) explains that this species is often caught for sale outside of Karakelang Island. Research on breeding has been done by Mayasari and Suryawan (2013), concluding that acclimatization of Red and Blue Lory takes a long time, the information about ecology and the appropriate can cage greatly determines the success of reproduction.

The diversity of herpetofauna species is affected by the land covers; it is more common in the forest area than the garden (Subasli 2015). All Herpetofauna and Arthropods at this research is found in coastal ecosystems, such as in the piles of nekromass, tree and beaches. The E. caeruleocauda has been distributed in the Pacific Islands, i.e., the small island of Federated State of Micronesia which is poorly known biologically (Buden 2013). Linkem et al. (2013) concludes the L. smaragdina is the species with excellent dispersal capabilities and it invades the Sangir-Talaud, Banggai Island, New Guinea, Solomon Island and West Pacific. E. multicarinata is often found in the Philippines (Barley et al. 2013). L. laticaudata (Bluebanded sea kraits) is one of third of Laticauda groups (sea kraits) and the widest distribution species with relatively intermediate dehydration rates in seawater (Brischoux et al. 2013; Gherghel et al. 2016).

Based on Buden (2007) E. caeruleocauda is one of the fifth species of skinks sympatric of the genus Emoia. Based on studies of Barley et al. (2013) in several species of herpetofauna, the phylogenetic analysis needs to be done, because it is genetically unrelated but morphologically similar to each other. DNA and morphological analysis results have made it to be divided into sub species of $E$. multicarinata multicarinata, E. multicarinata borealis, Eutropis sp. and E. bontocensis.

Birgus lastro is the largest terrestrial crab in the world and distributed on Indo-Pacific island, but it is declined rapidly (Drew et al. 2010), because it has high economic value for local community and can be sold at high prices (Widiyanti et al. 2016). Jahidin (2010) has estimated that the population of it in Siompu Island (near Buton Island) is only 44 individuals. Christmas Island has the highest population of B lastro reaching 962 individuals, but today the population is declining (Drew and Manson 2014). Based on Sulistiono et al. (2009b) to breed B. latro was quite difficult, and the survival rate in captivity was only $12.5 \%$. Sulistiono et al. (2009a) explains that the survival rate can increase to $82 \%$ through the addition of freshwater and seawater in the breeding pond.

\section{Habitat ecology}

Based on the observations, the highest diversity of wildlife species is found in coastal ecosystems, even though the area is dominated by coconut trees. It is suspected due to the presence of mangrove forests around 
coastal ecosystems. Mangrove forest is dominated by Lumnitzera littorea and Xylocarpus mekongensis (MMAF 2015). Mangrove forest is a habitat for birds and other wildlife. It is in accordance with Oostra et al. (2008) that the existence of the forest gives very positive effect on the abundance of bird species. According to Kuswanda (2010), plant species composition of the forests is the most influential factor on the index of diversity, abundance, and density of birds.

The existence of forests is the best assurance of the long-term survival of avifauna sustainability (Oostra et al. 2008). Miangas Island only has $2.4 \%$ area of primary forest, consisting of mangrove and lowland forest ecosystems on the hill which has been sacred by the people. The other existing ecosystems are coastal forest which has been dominated by coconut plant, mangrove forest, lowland forest, plantation, and settlements. On the other hand, Buden (2007) says that E. caeruleocauda prefers the shady forest. The existence of bird species has a close relationship with its habitat, Sukandar et al. (2015) explains that kingfisher species has high dependence on forest and aquatic ecosystem, so it is often used as a health indicator of ecosystem.

On coastal ecosystems, we can find 10 species of birds such as Long tail shrike, The Collared kingfisher, Talaud kingfisher, Pacific reef-egret, White Egret, Himalayan Cuckoo, Eurasian Tree Sparrow, Pacific Swallow, Olive Backed Sunbird, Red and Blue Lory and The Grey Wagtail. In the lowland forests which is located in Bukit Keramat and dominated by grassland and some trees, we can find five species of birds, such as: Grey Faced Buzzard, Olive Backed Sunbird, The white-throated needletail, Redthroated sparrow and Grey Imperial Pigeon. This proves that the diversity of wild animal is higher in thick forests than in thin forests.

A seawall has been built along the coastal islands, it affects the life cycle of $L$. laticaudata. Based on Gherghel et al. (2016) the life cycle of L. laticaudata is $19,75 \%$ in land and $80,25 \%$ in seawater. The seawall causes L. laticaudata having difficulty to reach the mainland. Rasmussen et al. (2011) concludes that sea snake population has decline.Some populations of species which used to go up the rivers or main land are already extinct and others are endangered.

This research needs to be completed by calculating the population density, the diversity index, the importance value index of species in each habitat, so that the ecological can be monitored. The time and duration influence the number of species (Marshal 2015).This study is only carried out for 3 days in each visit. This research also needs a support from the nocturnal wildlife diversity information, so the data can be used as the basis for Miangas Island development.

Fox (2008) explains that animal identification using acoustic individual recognition is a noninvasive method which has several benefits namely: time saving, relatively low cost, and easy to apply. In addition, the need for monitoring genetic diversity, particularly endangered species (Eos histrio) in small habitats is urgent. Charpentier et al. (2007) explains that a decrease in genetic variability is likely to reduce the capability for adaptation to change and adaptation to unpredictable environments, and this capability is proportional to the genetic variance. Meanwhile, according to Waltert et al. (2004) endemic species is the most vulnerable to the slightest changes in forest functions. Even if the changes occur in the secondary forest that is located very close to the primary forest. The species that can adapt to the change is the nectarivorous frugivorous bird. The coastal ecosystem can provide fruits and flowers all year round both from coconut trees, mangroves, and coastal vegetation.

\section{Challange and recommendation}

Mangrove ecosystems and lowland forest in Bukit Keramat are the last primary forest in the Miangas Island. But unfortunately, the mangrove ecosystems hardly ever get the tidal supplies. In the rainy season, the mangrove vegetation will always submerge by fresh water, whereas, there is no water flow passing through the vegetation in the dry season, unless there is a big wave coming. This condition will gradually decrease the salinity, which in turn can lead to the death of mangrove vegetation. The loss of tidal supplies is caused by the construction of seawall encircling the island since 2014.

According to Nurse et al. (2014) small island biodiversity will experience high pressure due to climate change that is 1) ecosystem and species horizontal shifts and range decline; 2) exotic and pest species range increase and invasions mainly due to temperature increase in high latitude islands; 3) altitudinal species range shifts and declines mainly due to temperature increase on high island. Larrue et al. (2014) describes how the invasive species has become a serious problem in tropical islands especially on the island of Hawaii. This will certainly have an impact on the carrying capacity of the habitat to wildlife and human life. Habitat is very important for the survival of living beings. Based on the analysis of Heriyanto et al. (2008), habitat quality and quantity give more impact to the preservation of wildlife than a hunting does. So it takes the effort to conserve habitat and wildlife as well as enriching the vegetation species to support the preservation of ecosystems and life on the island of Miangas.

Other challenges faced by Miangas Island, which the intrusion of sea water has reached 500 meters from the beach, are abrasion and soil degradation (Suryawan et al. 2015, pers. obs.) and it is estimated that the reserves of fresh water will not be able to meet the need in 2030 (Sarbidi 2010). Nurse et al. (2014) also explain that the porosity of the limestone and the coral causes the rapid surface flow to enter the substrate so that the vegetation will experience the lack of fresh water. Tanaguchi (2016) predicts that future climate conditions will be dominated by rain with low intensity, thus it will reduce the water infiltration. The forest is the only hope to preserve water resources in Miangas Island which will also serve as a wildlife habitat. Yuniati et al. (2013) suggest the existence of customary forests or village forests is the best management system to be implemented. 


\section{ACKNOWLEDGEMENTS}

The author thanks to Head of Environment and Forestry Research and Development Institute of Manado for supporting this research, all technicians of collecting the data and Miangas's peoples for support and hospitality.

\section{REFERENCES}

Ahmad Z, Sinyo Y, Ahmad H, Tamalene MN, Papuangan N, Abdullah A, Bahtiar, Hasan S. 2017. Bird species diversity at tourist attraction Ternate City : effort to know and conserve endemic bird habitat. J. Saintifik 1 (1) : $26-31$.

Alamsyah M, Marhento G. 2016. Identification of bird species diversity and local wisdom in conservation of Rambut Island, Kepulauan Seribu. J. Formatif 6 (2) : 119 - 124.

Anagnostou C, Schubert CD. 2014. Morphometric characterisation of a population of adult coconut crabs Birgus latro (Decapoda: Anomura: Coenobitidae) from Christmas Island in the Indian Ocean. Raffles Bul Zoo 30: 136-149.

Arini DID. 2014. Roost Tree Characteristics and Selection by Red and Blue Lories (Eos histrio Muller, 1776) in Karakelang Island-Talaud Islands, North Sulawesi. [Thesis]. Gadjah Mada Univesity, Yogyakarta. [Indonesian]

Arini DIDI, Pudyatmoko S, Poedjirahajoe E. 2016. Roosting selection by red and blue Lories (Eos histrio Muller,1776) in Karakelang Island North Sulawesi. J Wallacea 6 (1): 73-84.

Barley A, White J, Diesmos AC, Brown RM. 2013. The challenge of species delimitation at the extremes: diversification without a morphological change in Philippine Sun Skinks. J Evolution 67 (12): 3556-3572.

Beukema W. 2011. Herpetofauna of distributed forest fragment on the lower Mt. Kitanglad range, Mindanau, Philipina. J Salamandra 47 (2): 90-98.

BirdLife. 2016. IUCN Red List for birds. www.birdlife.org

Bismark. 2011. Standard Operational Procedure for Species Diversity Survey In Conservation Area. Bogor: Forest Research and Development Ministry of Forestry. [Indonesia]

Brischoux F, Tingley R, Shine R, Lillywhite HB. 2013. Behavioral and physiological correlates of the geographic distributions of amphibious sea kraits (Laticauda spp.). J of Sea Research 76: 1-4.

Buden DW. 2007. Reptiles of Satawan atoll and the Mortlock Islands, Chuuk State, Federated States of Micronesia. J Pacific Scie 61 (3) 425-428.

Burung.org. 2016. 167: Sangihe and Talaud. www.burung.org

BPS[Statistic Talaud District]. 2014. Miangas District on Figure. Statistic Talaud District, Melonguane, Talaud.

Charpentier MJE, Widdig A., Alberts SC. 2007. Inbreeding depression in non-human primates: a historical review methods used and empirical data. Amer J Primate 69: 1370-1386.

Cept.net. 2016. Terrestrial, Marine Corridors Wallacea Map. www.cepf.net

Coates BJ, Bishop KD, 2000. A Field Guide to The Birds of Wallacea (Sulawesi, Moluccas and Nusa Tenggara). Vogelbescherming, Belanda: SMK Desa Putra.[Indonesian]

Datta-roy A, Deepak V, Sidharthan C, Barley AJ, Praveen K. 2015. An addition to endemic Indian radiation of Eutropis: phylogenetic position of Eutriois dissimilis Hallowell (Squamata: Scincidae). J Zootaxa 4027 (1): 145-150

Drew MM, Harzch Stenssmyr M, Erland S, Hansson BS. 2010. A review of the biology and ecology of the robber crab, Birgus latro (Linnaeus, 1767) (Anomura: Coenobitidae). J Compar Zool 249 (1): 45-67.

Drew MM, Hanson BS. 2014. The population structure of Birgus latro (Crustacea: Decapoda: Anomura: Coenobitidae) on Christmas island with incidental notes on behaviour. Raffles Bull Zool 30: 150-161.

Fachrul MF. 2008. Bioecology Sampling Methods. Bumi Aksara, Jakarta. [Indonesian]

Fitzsimons JA, Thomas JL, Argeloo M. 2011. Occurrence and distribution of established and new introduced bird species in North Sulawesi, Indonesia. J Forktail 27: 23-28.
Fox EJS. 2008. A new perspective on acoustic individual recognition in animal with limited call sharing or changing repertoires. J Anim Behav 75: 1187-1194.

Gherghel I, Papes M, Brischoux F, Sahlean T, Strugariu A. 2016. A revision of the distribution of sea kraits (Reptilia, Laticauda) with an updated occurrence dataset for ecological and conservation research. J Zookeys 569: 135-148.

MMAF. 2015. Public Consultation Meeting Compilation of Zoning and Masterplan Plan of Miangas, Marampit and Kakorotan Island. Regency of Talaud Islands. Ministry of Marine Affairs and the Fisheries Republic of Indonesia. Melonguane, 27 September 2015 [Indonesia]

Heriyanto NM, Garsetiasih R, Setia P. 2008. Population status and habitat of birds in Bayah Forest district, Banten. J Penelitian Hutan dan Konservasi Alam 5 (3): 239-249.

Indrawan M. 2005. Preliminary notes for the seminar Indonesian ornithologists' union national ornithological seminar; Proceeding of Seminar Ornithology Indonesia, Bogor, 19-20 Maret 2004. [Indonesian]

IUCN. 2016. The IUCN Red List of Threatened Species. www.IUCN

Jahidin. 2010. Estimated population of coconut crab (Birgus latro) in Siompu Island. J Berk Pen Hayati 15: 139-142.

Kaiser H, Carvalho LV, Ceballos J, Freed P, Heacox S, Lester B, Richard SJ, Trainor CR, Sanches C, O'Shea M. 2011. The herpetofauna of Timor-Leste: a first report. J Zookeys 109 (109): 19-86.

Karar A, Ningsih S, Ihsan M. 2016. Bird diversity at primary forest in Pasoso Island Wildlife Reserve, Balaesang Tanjung District, Donggala. J. Wrt Rimba 4 (1) : 1 - 8

Koch A, Aryda E, Riyanto A. 2009. Islands between the realms: a revised checklist of the herpetofauna of the Talaud Archipelago, Indonesia with a discussion about its biogeographic affinities. J Bonner Zool Beit 56 (1/2): 107-129.

Koch A, Arida E, Schmitz A, Böhme W, Ziegler T. 2013. Refining the polytypic species concept of mangrove monitors (squamata: Varanus indicus group): a new cryptic species from the Talaud Islands, Indonesia, reveals the underestimated diversity of Indo-Australian monitor lizards [2009]. Austr J Zool 57 (1): 29-40.

Kuswanda W. 2010. Effect of plant composition on bird population in Batang Gadis National park, North Sumatera. J Pen Hut dan Kons Alam 7 (2): 193-213.

Larrue S, Daebler C, Vantier F, Buffora JL. 2014. Forest invasion by the African tulip tree (Spathodea campunulata) in the Hawaiian island: area seedling shade-tolerant. J Pas Sci 68 (3): 345-358.

Linkem CW, Brown RM, Siler CD, Evans BJ, Austin CC, Iskandar DT, Diesmos AC, Supriatna J, Andayani N, McGuire JA. 2013. Stochastic faunal exchanges drive diversification in widespread Wallacean and Pacific island lizards (Squamata: Scincidae: Lamprolepis smaragdina). J Biogeogr 40 (3): 507-520.

Lubis MSN. 2014. Model Management of Small Isles Outlying Based on Sociecological System Approach, Socioeconomic System, and Sociopolitical System (Case Study of Lingayan Island Central Sulawesi) [Desertation]. Universitas Diponegoro, Semarang [Indonesia]

Marshal AJ. 2015. Introduction of Vertebratory Animal Survey Methods (Especially Large Vertebrates). Univeristy of Michigan, Michigan [US America]

Mayasari A, Suryawan A. 2013. The daily of nuri Talaud (Eos histrio) in captivity of manado forestry research institute. Proceeding of Forest and Biodiversity International Conference. Forestry Research Institut of Manado, Manado, 5-6 Juni 2013. [Indonesian]

Mbora DNM, Mcpeek MA. 2010. Endangered species in small habitat patches can possess hight genetic diversity: the case of the Tana river red Colobus and Mangabey. J Conserv Genet 11 (5): 1725-1735.

Motoh H, Kuronuma K. 1980. Field guide for the edible Crustacea of the Philippines. Aquaculture Department, Southeast Asian Fisheries Development Center, Illoilo. [Philippines]

Nurse LA, Mclean RF, Agard J, Briguglio LP, Duvat-Magnan V, Pelesikoti N, Tompkins E, Web A. 2014. Small islands. In: Baros VR, Field CB, Dokken DJ et. Climate Change: Impacts, Adaptation And Vulnerability. Part B: Regional Aspect Contribution of Working Group II To The Fifth Assesment Report Of The Intergovernmental Panel On Climate Change. Cambridge University Press, UK.

Oostra V, Laurens GL, Gomes, Nijman V. 2008. Implication of deforestation for abundance of restricted-range bird species in a Costa Rican cloud forest. J Bird Conserv Intl 18 (1): 11-19. 
Purnomo DW, Solihah SM, Sumanto. 2015. Conservation value and environmental services of the plant collections of botanic gardens at the urban area. Pros Sem Nas Masy Biodiv Indon 1 (8): 1851-1855 [Indonesian]

Rasmussen AR, Murphy JC, Opmi M, Gibbsons JW, Uetz P. 2011. Review marine reptiles. PloS One 6 (11): 1-12.

Sarbidi. 2010. Study availability for water raws in small island: case study in Miangas Island. J Permukiman 5 (3): 139-146.

Saryanti, R. 2013. Preparation of the ecosystem profile for Wallacea. Proceeding International Forest and Biodiversity Conference. Forestry Research Institut of Manado, Manado, 5-6 June 2013. [Indonesian]

Sulistiono, Kamal MM, Butet NA. 2009 a. Preliminary study on the coconut crab (Birgus latro) rearing in captive pond. J Akuakul Ind 8(1): 101-107.

Sulistiono, Refiana S, Tantu FR, Muslihuddin. 2009b. Preliminary study on domestication of coconut crab (Birgus latro). J Akuakul Ind 8(2): 183-189.

Suryawan A, Yuliantoro I, Asmadi N, Shabri S, Diwi MS. 2015. A Report Research Result of Conservation and Rehabilitation Technique on Border Island Together with the Community [unpublished]. Environment and Forestry Reseach and Development Institut Manado. Manado, 28 December 2015 [Indonesian]
Stelbrink DBB, Albrecht C, Hall R, Rintelen TV. 2012. The biogeography of Sulawesi revisited: is there evidence for a vicariant origin of taxa on Wallace's “anomalous island” ?. J Evolution 66 (7): 2252-2271.

Stelbrink DBB. 2014. A Biogeographic View On Southeast Asia's History. [Dessertation]. Universitat Zu Berlin, Berlin [Germany]

Taniguchi K. 2016. Future change in precipitation and water resources for Kanto region in Japan after application of pseudo global warming method and dynamical downscaling. J Hidrol: Regional Stud 8 (C): 287-303.

Yuniati TW, Persoon G, Awang SA. 2013. Option for biodiversity conservation of Gunung Lumut Protection Forest East Kalimantan. Proceeding of Forest and Biodiversity International Conference: 6980. Forestry Research Institut of Manado, Manado, 5-6 Juni 2013. [Indonesian]

Waltert M, Mardiastuti A, Muhlenberg M. 2004. Effect of land use on bird species richness in Sulawesi, Indonesia. J Conserv Biol 18 (5): 13391346.

Widiyanti SE, Marsoedi, Sukosi, Setyohadi D. 2016. Population dynamic of coconut crab (Birgus latro) in Sayafi Island, North Maluku of Indonesia. J Biodiv Environ Sci 8 (6): 151-161.

Woodruff DS. 2010. Biogeography and conservation in Southeast Asia: how 2.7 million years of repeated environmental fluctuations affect today's pattern and the future of the remaining refugial-phase biodiversity. Biodiv Conserv 19 (4): 919-941. 